\title{
ANALYZING MATHEMATICAL LITERACY ABILITIES IN TERMS OF COGNITIVE STYLE OF SIXTH GRADE STUDENTS: A CASE STUDY AT SD INPRES NIPA-NIPA
}

\author{
Nurul Wulan ${ }^{1}$, Sukmawati $^{2}$, Baharullah $^{3}$ \\ ${ }^{1,2,3}$ Universitas Muhammadiyah Makassar, Makasar, Indonesia \\ ${ }^{I}$ nurul.wulan17@yahoo.co.id
}

\begin{abstract}
This study aimed to describe the Mathematical literacy skills of Grade VI students of SD Inpres Nipa-Nipa, in terms of reflective and impulsive cognitive styles, based on the six levels of Mathematical literacy. This research was a descriptive study with a qualitative approach. The subjects of this study were two grade IV students, one student with a reflective style and another student with an impulsive style. The data collection began by giving a cognitive style test and an initial Mathematics test. Then, a Mathematical literacy test was also administered to determine the level of students' literacy. After that, an interview was conducted to obtain more accurate data. The results showed that (1) the reflective student took a long time and was very circumspect in answering the Mathematical literacy test questions, so that the results were more accurate. The reflective student was able to answer the questions with clear procedures sequentially and was able to interpret and use representations based on information of the questions, so that it could take the right strategy to answer the question. These results revealed that the students were at the third level of mathematical literacy ability, (2) the impulsive student needed shorter time and was less careful in answering a Mathematical literacy test so that the results were less accurate. The results showed that the impulsive student could answer the question with an identified context and the relevant information with a clear question was available. In addition, the impulsive student could identify information obtained from the question and when he was given a stimulus. Thus, the impulsive student possessed the first-level of Mathematical literacy skills.
\end{abstract}

Keywords: mathematical literacy, cognitive style

\section{ANALISIS KEMAMPUAN LITERASI MATEMATIKA DITINJAU DARI GAYA KOGNITIFSISWA KELAS VI SD INPRES NIPA-NIPA TIPE STUDI KASUS}

\begin{abstract}
ABSTRAK
Penelitian ini bertujuan untuk mendeskripsikan kemampuan literasi Matematika siswa Kelas VI SD Inpres Nipa-Nipa yang ditinjau dari gaya kognitif reflektif dan impulsif berdasarkan enam level literasi Matematika. Penelitian ini merupakan penelitian deskriptif dengan pendekatan kualitatif. Subjek penelitian ini adalah satu siswa kelas VI, dua siswa yang bergaya reflektif, dan satu siswa yang bergaya impulsif. Pengambilan data dimulai dengan memberikan tes gaya kognitif dan tes kemampuan awal Matematika. Dilanjutkan dengan memberikan tes literasi Matematika untuk mengetahui level literasi yang dimiliki oleh kedua subjek penelitian. Kemudian dilanjutkan dengan wawancara untuk memperoleh data yang lebih akurat. Hasil penelitian menunjukkan bahwa, (1) siswa reflektif membutuhkan waktu yang lama dan sangat berhati-hati ketika mengerjakan soal tes literasi Matematika, sehingga hasil yang diberikan lebih akurat. Siswa reflektif tersebut mampu menjawab soal dengan prosedur yang jelas secara berurutan, dan mampu menafsirkan serta menggunakan representasi berdasarkan informasi yang diperoleh dari soal sehingga dapat mengambil strategi yang tepat untuk menyelesaikan soal tersebut, sehingga hasil yang diperoleh menunjukkan bahwa siswa tersebut memiliki kemampuan literasi Matematika level 3; (2) siswa impulsif membutukan waktu yang singkat dan kurang berhhati-hati ketika mengerjakan tes literasi Matematika sehingga hasil yang dikerjakan kurang akurat. Adapun hasil yang diperoleh menunjukkan bahwa siswa impulsif mampu menyelesaikan soal dengan konteks yang dikenal serta semua informasi yang relevan tersedia dengan pertanyaan yang jelas. Selain itu, siswa impulsif tersebut dapat mengidentifikasi informasi yang diperoleh dari soal dan ketika diberikan stimulus. Dengan demikian, siswa impulsif tersebut memiliki kemampuan literasi Matematika level satu.
\end{abstract}

Kata Kunci: literasi matematika, gaya kognitif

\begin{tabular}{|c|c|c|}
\hline Submitted & Accepted & Published \\
\hline 01 Februari 2021 & 19 Juli 2021 & 28 Juli 2021 \\
\hline
\end{tabular}

\begin{tabular}{|l|c|c|}
\hline Citation & $:$ & $\begin{array}{r}\text { Wulan, N., Sukmawati, S., \& Baharullah, B. (2021). Analyzing Mathematical Literacy Abilities in Terms of Cognitive Style } \\
\text { of Sixth Grade Students: A Case Study at SD Inpres Nipa-Nipa. Jurnal PAJAR (Pendidikan dan Pengajaran), } \\
5(4), 1065-1078 . \text { DOI : } \text { http://dx.doi.org/10.33578/pjr.v5i4.8304. }\end{array}$ \\
\hline
\end{tabular}

\section{PENDAHULUAN}

Permendikbud Nomor 23 Tahun 2015 berupaya untuk menumbuhkan budi pekerti peserta didik melalui serangkaian kegiatan yang harus dilakukan oleh peserta didik, guru, dan

tenaga kependidikan yang bertujuan untuk menumbuhkan kebiasaan yang baik dan membentuk generasi berkarakter positif, atau yang disebut dengan kegiatan pembiasaan. 
Membiasakan maupun memotivasi peserta didik untuk membaca dan menulis, guna menumbuhkan budi pekerti menjadi salah satu tujuan dikembangkannya Gerakan Literasi Sekolah. Gerakan ini diharapkan dalam jangka panjang dapat menghasilkan para peserta didik yang memiliki kemampuan literasi yang tinggi.

Menurut Cope dan Kalantzis (dalam Abidin; Mulyati; Yunansah, 2017), literasi merupakan elemen terpenting dalam proyek pendidikan modern. Salah satu literasi yang sedang diterapkan di sekolah dasar adalah literasi matematika. Dalam proses pembelajaran matematika, kemampuan literasi merupakan salah satu kemampuan yang harus dimiliki siswa. Literasi matematika memiliki peran penting dalam membantu siswa menyelesaikan masalah yang berkaitan dengan penerapan matematika dalam kehidupan (Hasanah,2016).

Namun, meskipun pengembangan kemampuan literasi matematika siswa penting untuk dikembangkan, pada kenyataannya kemampuan siswa dalam memecahkan berbagai permasalahan dalam kehidupan sehari-hari masih rendah. Fakta di lapangan menyatakan bahwa capaian literasi Matematika di Indonesia masih tergolong rendah. Hal tersebut ditinjau dari mutu akademik antar bangsa melalui Programmme for International Student Assessment (PISA) di bidang Matematika pada tahun 2003, siswa Indonesia berada pada peringkat ke-39 dari 40 negara sampel, tahun 2006 Indonesia berada pada peringkat ke-38 dari 41 negara, tahun 2009 Indonesia berada pada peringkat ke-61 dari 65 negara, kemudian tahun 2015 Indonesia berada pada peringkat ke-62 dari 70 negara, selanutnya pada tahun 2018 peringkat Indonesia mengalami penurunan. Hal tersebut dibuktikan oleh hasil tes yang dilakukan oleh dua studi internasional, yaitu Trends in InternationalMathematics and Science Study (TIMSS) dan Programme for InternationalStudent Assesment (PISA). Hasil studi Programme for International Student Assesment yang dirilis pada hari Selasa, 3 Desember 2019 menyatakan bahwa peringkat PISA tahun 2018 mengalami penurunan, untuk kategori Matematika, Indonesia berada pada peringkat 7 dari bawah atau 73 dari 79 negara dengan skor rata-rata 379.

Berdasarkan data tersebut, kemampuan literasi siswa-siswi Indonesia belum mengalami peningkatan yang signifikan dari tahun 2003 sampai tahun 2018 karena mengalami peningkatan dan penurunan sehingga masih tergolong rendah. Hal ini menunjukkan kemampuan siswa Indonesia dalam menyelesaikan soal-soal berupa soal telaah, memberi alasan, mengkomunikasikan, dan memecahkan serta menginterpretasikan berbagai permasalahan masih sangat rendah. Hal tersebut menjadi koreksi bersama bahwa soal-soal Matematika dalam studi PISA lebih banyak mengukur kemampuan bernalar, memecahkan masalah dan berargumentasi daripada mengukur kemampuan ingatan dan perhitungan (Kemendikbud, 2016).

Dari hasil wawancara peneliti dengan guru wali kelas VI di SD Inpres Nipa-Nipa, diperoleh informasi bahwa siswa di kelas tersebut memiliki cara penyelesaian soal yang berbedabeda sesuai dengan kemampuan mereka, khususnya untuk soal Matematika yang menuntut kemampuan penalaran yang tinggi. Ketika siswa diberikan soal-soal dengan level C4-C6, siswa tersebut tidak dapat menyelesaikannya. Contohnya untuk soal dengan ranah kognitif C4 berikut "Sebuah gudang penyimpanan beras mempunyai persediaan 1,5 ton beras. Keesokan harinya sebanyak 7.2 kuintal beras dibagikan kepada masyarakat. Kemudian untuk menambah persediaan beras, pengelola membeli lagi $490 \mathrm{~kg}$ beras. Tentukan berapa kuintal persediaan beras dalam gudang sekarang!". Ketika siswa dihadapkan pada soal tersebut, mereka tidak dapat mengerjakan dengan baik soal tersebut, mereka langsung masuk pada operasi hitung tanpa menganalisis soalnya agar satuannya dirubah terlebih dahulu. Dan ketika siswa diberikan soal dengan level $\mathrm{C} 1-\mathrm{C} 2$, hanya $75 \%$ dari 36 siswa yang dapat mengerjakannya, kemudian ketika siswa diberikan soal dengan level C3, hanya $25 \%$ dari 36 siswa yang dapat mengerjakannya. Dengan demikian, siswa tidak dapat mengerjakan soal cerita yang menuntut penalaran siswa, sebagian besar siswa tidak mampu mengerjakan soal tersebut. Mereka tidak mampu memilih, 
membandingkan, dan mengevaluasi dengan tepat strategi pemecahan masalah terkait dengan apa yang diminta dari soal tersebut. Dan sebagian besar siswa hanya dapat menyelesaikan soal-soal skala bawah, dimana soal tersebut adalah soal dengan konteks yang cukup dikenal oleh siswa dan membutuhkan operasi matematika yang sederhana.

Selain hasil dari wawancara peneliti dengan guru wali kelas VI, hasil pengamatan pra penelitian yang dilakukan oleh peneliti terhadap sekolah tersebut menunjukkan bahwa di sekolah tersebut tidak memiliki sudut baca di setiap kelasnya, meskipun di sekolah tersebut terdapat perpustakaan umum, namun guru tidak memanfaatkannya secara maksimal. Selain itu, siswa juga merasa malas keluar kelas untuk membaca di perpustakaan. Dalam hal ini, sudut baca sangat penting diadakan di setiap kelas mengingat dalam RPP, sebelum memulai proses pembelajaran siswa di arahkan untuk melakukan kegiatan literasi selama lima sampai 15 menit. Tidak adanya sudut baca di kelas semakin membuat siswa malas untuk mengetahui banyak hal dari hasil membaca. Dalam hal ini, membaca yang dimaksud tidak hanya berfokus pada bahasa saja, tetapi bagaimana siswa mengetahui dan mampu menyelesaikan masalah-masalah dari buku-buku yang dibaca yang sudah disiapkan guru pada sudut baca di kelas. Karena literasi Matematika juga berkaitan dengan bagaimana siswa mampu memahami permasalahan yang ada dan menemukan solusi dari permasalahan tersebut.

Dengan demikian, dapat disimpulkan bahwa hasil wawancara dan hasil pengamatan pra penelitian yang dilakukan oleh peneliti menunjukkan bahwa kemampuan literasi matematika siswa kelas VI SD Inpres Nipa-Nipa masih tergolong rendah, hampir sebagian besar siswa tidak dapat melakukan apa yang seharusnya dilakukan saat mengerjakan soal-soal Matematika terkait dengan keenam level literasi Matematika yang dikembangkan oleh PISA.

Secara alamiah, kemampuan siswa dalam menyelesaikan masalah Matematika berbedabeda, baik dalam cara pendekatan terhadap situasi belajar, dalam cara menerima, serta mengorganisasi dan menghubungkan pengalaman-pengalaman mereka. Damarah dalam Zairozie (2016) mengemukakan bahwa perbedaan indivdu dalam menyelesaikan masalah disebabkan karena perbedaan psikologi masing-masing individu, salah satunya adalah aspek gaya kogntif.

Desmita (2009) menjelaskan bahwa gaya kognitif adalah karakteristik individu dalam menggunakan fungsi kognitif (berpikir, mengingat, memecahkan masalah, dan sebagainya) yang bersifat konsisten dan lama. Alamolhodae dalam Mallisa (2015) mengemukakan bahwa siswa dengan gaya kognitif yang berbeda akan memiliki perbedaan pendekatan atau pengolahan informasi dan memecahkan masalah Matematika dengan cara yang berbeda pula. Oleh karena itu, tidak menutup kemungkinan siswa yang memiliki gaya kognitif yang berbeda akan memiliki juga kemampuan yang berbeda dalam memecahkan masalah literasi Matematika. Hal tersebut juga sejalan dengan pendapat Collins dalam Ningsih (2012) yang mengatakan bahwa siswa yang memiliki gaya kognitif yang berbeda akan menyelesaikan masalah dengan berbeda pula, sehingga perbedaan gaya kognitif akan memicu perbedaan kemampuan siswa dalam memecahkan masalah Matematika yang berkaitan dengan kehidupan sehari-hari.

Dewasa ini, telah banyak dikenal jenisjenis gaya kognitif. Diantaranya adalah gaya kognitif reflektif dan gaya kognitif impulsif. Siswa yang memiliki gaya kognitif reflektif mempunyai karakteristik cenderung menggunakan lebih banyak waktu untuk merespon dan merenungkan akurasi jawaban. Indivdu reflektif sangat lamban dan berhati-hati dalam memberikan respons, tetapi cenderung memberi jawaban secara benar. Sedangkan siswa yang memiliki gaya impulsif cenderung memberikan respons secara cepat. Indivdu impulsif sejati adalah indivdu yang memberikan respons sangat cepat, tetapi juga melakukan sedikit kesalahan dalam proses tersebut (Desmita, 2009:146). Kedua gaya kognitif tersebut sangat unik untuk diketahui level kemampuannya dalam literasi matematika.

Berdasarkan uraian tersebut, maka peneliti akan melakukan penelitian dengan judul 
"Analisis Kemampuan Literasi Matematika Ditinjau dari Gaya Kognitif Siswa Kelas V SD Inpres Nipa-Nipa Tipe Studi Kasus”.

\section{KAJIAN TEORETIS}

Menurut Cope dan Kalantzis (dalam Abidin; Mulyati; Yunansah, 2017), literasi merupakan elemen terpenting dalam proyek pendidikan modern. Salah satu literasi yang sedang diterapkan di sekolah dasar adalah literasi Matematika. Dalam proses pembelajaran Matematika, kemampuan literasi merupakan salah satu kemampuan yang harus dimiliki siswa. Literasi matematika memiliki peran penting dalam membantu siswa menyelesaikan masalah yang berkaitan dengan penerapan Matematika dalam kehidupan (Hasanah,2016).

Secara sederhana, literasi Matematika dapat diartikan sebagai kemampuan memahami dan menggunakan Matematika dalam berbagai konteks untuk memecahkan masalah, serta mampu menjelaskan kepada orang lain bagaimana menggunakan Matematika (Abidin, Mulyati,
Yunansah, 2017 : 100). Dalam konteks PISA, literasi matematika dianggap sebagai salah satu komponen penting yang dibutuhkan untuk dapat menyelesaikan soal-soal PISA. Soal-soal PISA sangat menuntut kemampuan penalaran, komunikasi, dan pemecahan masalah. Seseorang dikatakan mampu menyelesaikan masalah apabila mampu menerapkan pengetahuan yang telah diperoleh sebelumnya ke dalam situasi baru yang belum dikenal (Lencher dalam Abidin, Mulyati, Yunansah, 2017:101).

Adapun soal-soal yang diberikan kepada siswa berdasar pada enam indikator level literasi Matematika yang dikembangkan oleh PISA (OECD dalam Syawahid dan Putrawangsa, 2017). Dengan soal-soal yang diberikan kepada siswa, peneliti dapat mengetahui apa-apa saja yang dapat dilakukan oleh siswa sehingga dari jawaban siswa tersebut, diperoleh kemampuan literasi Matematika siswa berada pada level berapa dengan berpedoman pada keenam level literasi Matematika yang dikembangkan oleh PISA. Keenam level tersebut adalah sebagai berikut.

Tabel 1. Kriteria Level Literasi Matematika menurut PISA

\begin{tabular}{|c|c|}
\hline Level & Deskripsi \\
\hline 1 & $\begin{array}{l}\text { a. Siswa dapat menjawab pertanyaan dengan konteks yang dikenal serta semua } \\
\text { informasi yang relevan tesedia dengan pertanyaan yang jelas. } \\
\text { b. Siswa dapat mengidentifikasi informasi, dan melakukan cara-cara yang umum } \\
\text { berdasarkan instruksi yang jelas. } \\
\text { c. Siswa dapat menunjukkan suatu tindakan sesuai dengan stimulasi yang diberikan. }\end{array}$ \\
\hline 2 & $\begin{array}{l}\text { a. Siswa dapat menafsirkan dan mengenali situasi dengan konteks yang memerlukan } \\
\text { kesimpulan langsung. } \\
\text { b. Siswa dapat memilah informasi yang relevan dari sumber tunggal, dan } \\
\text { menggunakan cara penyajian tunggal. } \\
\text { c. Siswa dapat mengerjakan algoritma dasar, menggunakan rumus, melaksanakan } \\
\text { prosedur atau kesepakatan. } \\
\text { d. Siswa dapat memberi alasan secara tepat dari hasil penyelesainnya }\end{array}$ \\
\hline 3 & $\begin{array}{l}\text { a. Siswa dapat melaksanakan prosedur dengan jelas, termasuk prosedur yang } \\
\text { memerlukan keputusan secara berurutan. } \\
\text { b. Siswa dapat memecahkan masalah, dan menerapkan stratregi yag sederhana. } \\
\text { c. Siswa dapat menafsirkan dan menggunakan representasi berdasarkan sumber } \\
\text { informasi yang berbeda dan mengemukakan alasannya secara langsung. } \\
\text { d. Siswa dapat mengkomunikasikan hasil interpretasi dan alasan mereka. }\end{array}$ \\
\hline 4 & $\begin{array}{l}\text { a. Siswa dapat bekerja secara efektif dengan model dalam situasi yang konkret } \\
\text { tetapi kompleks yang mungkin melibatkan pembatasan untuk membuat asumsi. }\end{array}$ \\
\hline
\end{tabular}




\begin{tabular}{c|l}
\hline & b. $\begin{array}{l}\text { Siswa dapat memilih dan menggabungkan representasi yang berbeda, termasuk } \\
\text { pada simbol, menghubungkannya dengan situasi nyata. }\end{array}$ \\
& c. $\begin{array}{l}\text { Siswa dapat menggunakan berbagai keterampilannya yang terbatas dan } \\
\text { mengemukakan alasan dengan beberapa pandangan dikonteks yang jelas. }\end{array}$ \\
d. $\begin{array}{l}\text { Siswa dapat memberikan penjelasan dan mengomunikasikannya disertai } \\
\text { argumentasi berdasar pada interpretasi dan tindakan mereka. }\end{array}$ \\
\hline $\mathbf{5}$ & a. $\begin{array}{l}\text { Siswa dapat mengembangkan dan bekerja dengan model untuk situasi kompleks, } \\
\text { mengidentifikasi masalah, dan menetapkan asumsi. }\end{array}$ \\
b. $\begin{array}{l}\text { Siswa dapat memilih, membandingkan, dan mengevaluasi dengan tepat strategi } \\
\text { pemecahan masalah terkait dengan permasalahan kompleks yang berhubungan } \\
\text { dengan model. }\end{array}$ \\
c. $\begin{array}{l}\text { Siswa dapat bekerja secara strategis dengan menggunakan pemikiran dan } \\
\text { penalaran yang luas. }\end{array}$ \\
d. $\begin{array}{l}\text { Siswa dapat melakukan refleksi dari pekerjaan mereka dan dapat merumuskan } \\
\text { dan mengkomunikasikan penafsiran dan alasan mereka. }\end{array}$ \\
a. $\begin{array}{l}\text { Siswa dapat melakukan pengonsepan } \\
\text { b. } \begin{array}{l}\text { Siswa dapat menghubungkan sumber informasi berbeda dan merepresentasi, dan } \\
\text { menerjemahkan diantara keduanya dengan fleksibel. }\end{array} \\
\text { c. } \begin{array}{l}\text { Siswa dapat menerapkan pengetahuan, penguasaan, dan hubungan dari simbol } \\
\text { dan operasi matematika, mengembangkan strategi dan pendekatan baru untuk } \\
\text { menghadapi situasi yang baru. }\end{array} \\
\text { d. Siswa dapat merefleksikan tindakan mereka dan merumuskan dan } \\
\text { mengomunikasikan tindakan mereka dengan tepat dan menggambarkan } \\
\text { sehubungan dengan penemuan mereka, penafsiran, pendapat, dan kesesuaian } \\
\text { dengan situasi nyata. }\end{array}$ \\
\hline
\end{tabular}

Dalam menyelesaikan masalah Matematika, secara alamiah kemampuan siswa berbeda-beda antara siswa yang satu dengan siswa yang lainnya, baik dalam cara pendekatan terhadap situasi belajar, dalam cara menerima, serta mengorganisasi dan menghubungkan pengalaman-pengalaman mereka. Damarah dalam Zairozie (2016) mengemukakan bahwa perbedaan individu dalam menyelesaikan masalah disebabkan karena perbedaan psikologi masingmasing indivdu, salah satunya adalah aspek gaya kogntif.

Desmita (2009 : 146) menjelaskan bahwa gaya kognitif adalah karakteristik individu dalam menggunakan fungsi kognitif (berpikir, mengingat, memecahkan masalah, dan sebagainya) yang bersifat konsisten dan lama. Alamolhodae dalam Mallisa (2015) mengemukakan bahwa siswa dengan gaya kognitif yang berbeda akan memiliki perbedaan pendekatan atau pengolahan informasi dan memecahkan masalah Matematika dengan cara yang berbeda pula. Oleh karena itu, tidak menutup kemungkinan siswa yang memiliki gaya kognitif yang berbeda akan memiliki juga kemampuan yang berbeda dalam memecahkan masalah literasi Matematika. Hal tersebut uga sejalan dengan pendapat Collins dalam Ningsih (2012) yang mengatakan bahwa siswa yang memiliki gaya kognitif yang berbeda akan menyelesaikan masalah dengan berbeda pula, sehingga perbedaan gaya kognitif akan memicu perbedaan kemampuan siswa dalam memecahkan masalah Matematika yang berkaitan dengan kehidupan sehari-hari.

Dewasa ini, telah banyak dikenal jenisjenis gaya kognitif. Namun, yang menjadi fokus peneliti dalam penelitian ini hanya dua, yaitu gaya kognitif relektif dan gaya kognitif impusif.. Siswa yang memiliki gaya kognitif reflektif mempunyai karakteristik cenderung menggunakan lebih banyak waktu untuk merespon dan merenungkan akurasi jawaban. Indivdu reflektif sangat lamban dan berhati-hati dalam memberikan respons, tetapi 
cenderung memberi jawaban secara benar. Sedangkan siswa yang memiliki gaya impulsif cenderung memberikan respons secara cepat. Indivdu impulsif sejati adalah indivdu yang memberikan respons sangat cepat, tetapi juga melakukan sedikit kesalahan dalam proses tersebut (Desmita, 2009:146). Kedua gaya kognitif tersebut digunakan oleh peneliti untuk mengetahui kemampuan literasi Matematika siswa.

\section{METODE PENELITIAN}

Jenis penelitian ini merupakan penelitian deskriptif dengan pendekatan kualitatif tipe studi kasus.dimana peneliti menyelidiki secara cermat suatu program, peristiwa, aktivitas, proses, atau sekelompok individu. Kasus-kasus dibatasi oleh waktu dan aktivitas, dan peneliti mengumpulkan informasi secara lengkap dengan menggunakan bebagai prosedur.

Penelitian ini dilakukan pada siswa kelas VI di SD Inpres Nipa-Nipa dengan memilih dua subjek penelitian, yaitu satu siswa yang bergaya kognitif reflektif dan satu siswa yang bergaya kognitif impulsif. Pengumpulan data dilakukan melalui tes MFFT untuk mengelompokkan siswa yang bergaya kognitif reflektif dan siswa yang bergaya kognitif impulsif yang diberikan kepada seluruh siswa kelas VI.A. Selanjutnya, siswa yang bergaya kognitif reflektif dan impulsif diberikan tes kemampuan awal Matematika untuk memlilih dua siswa, yaitu satu siswa reflektif dan satu siswa impulsif. Siswa reflektif dan impulsif yang dipilih berdasarkan nilai tertinggi yang diperoleh pada tes tersebut, kemudian dapat berkomunikasi secara lisan dengan baik sehingga peneliti dapat memperoleh informasi tentang kemampuan literasi Matematika siswa. Kemudian setelah terpilih dua siswa, maka siswa terpilih tersebut diberikan tes literasi Matematika dan wawancara mendalam terkait jawaban yang diberikan secara tertulis pada tes literasi Matematika untuk mengetahui kemampuan literasi Matematika yang dimiliki oleh masing-masing subjek terpilih tersebut.

Untuk menganalisa data penelitian tahap awal digunakan teknik analisis interaktif, dengan tiga komponen yang terdiri dari data reduction (reduksi data), data display (penyajian data), dan conclusion drawing/ verification (penarikan kesimpulan/ verifikasi). Reduksi data berarti merangkum, memilih hal-hal yang pokok, memfokuskan pada hal-hal yang penting, dicari tema dan polanya dan membuang yang tidak perlu. Penyajian data dilakukan dalam bentuk uraian singkat, bagan, hubungan antar kategori, maupun flowchart. Adapun pada tahhap penarikan kesimpulan, masih bersifat sementara, dan akan berubah bila tidak ditemukan bukti-bukti yang kuat yang mendukung pada tahap pengumpulan berikutnya.

\section{HASIL DAN PEMBAHASAN}

Untuk mengetahui kemampuan literasi Matematika siswa tersebut, maka diberikan tes literasi Matematika yang berjumlah enam soal. Soal tersebut dibuat peneliti dengan mengacu pada kriteria setiap level literasi Matematika yang dikembangkan oleh PISA, kemudian soal tersebut divalidasi oleh tim ahli. Kedua subjek penelitian terpilih tersebut berinisial RHR dengan pengkodean SPR (Subjek Penelitian Reflektif) dan ARS dengan pengkodean SPI (Subjek Penelitian Impulsif).

\section{Deskripsi Kemampuan Literasi Matematika Siswa yang Bergaya Kognitif Reflektif}

Berdasarkan hasil temuan pada siswa reflektif tersebut, maka siswa reflektif membutuhkan waktu yang lama dalam mengerjakan soal dan lebih berhati-hati dalam mengambil keputusan sehingga jawaban yang diberikan lebih akurat. Ketika SPR mengerjakan soal tes literasi Matematika, SPR membutuhkan waktu 1 jam 38 menit (98 menit) dari batas waktu pengerjaan yang diberikan selama 90 menit untuk menyelesaikan soal tes literasi Matematika tersebut. Setelah diberikan soal tes literasi Matematika kepada subjek RHR, hasil tes menunjukkan bahwa SPR (RHR) hanya mampu mengerjakan tiga soal dengan benar, yaitu soal nomor satu yang mengukur kemampuan literasi Matematika level 1, soal nomor dua yang mengukur kemampuan literasi Matematika level 2, dan soal nomor tiga yang mengukur kemampuan literasi Matematika level 3. 
Pada soal yang mengukur kemampuan literasi Matematika level 1 tersebut, siswa diberikan soal yang konteksnya umum dan dikenali oleh siswa yaitu gambar penghapus yang berbentuk balok. Kemudian setelah siswa melihat gambar penghapus, diharapkan siswa dapat menentukan rumus volume penghapus pada gambar tersebut. Adapun jawaban SPR pada soal nomor satu dapat dilihat pada gambar 1 berikut.

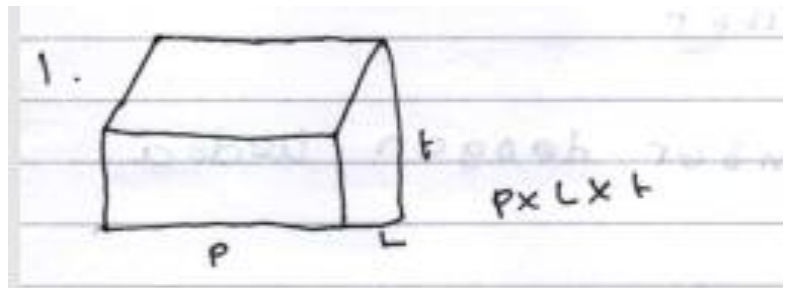

Gambar 1. Jawaban SPR untuk Soal Nomor 1

Dari hasil pengerjaan SPR tersebut, dapat dilihat bahwa siswa tersebut dapat mengerjakan soal nomor satu dengan benar. Dimana, siswa tersebut dapat menjawab rumus volume balok tersebut yang disertai dengan gambar balok. Hal tersebut menunjukkan bahwa SPR dapat menjawab pertanyaan tersebut dengan konteks yang dikenal yaitu gambar penghapus yang berbentuk balok. Selain itu, untuk mempertegas jawabannya, siswa tersebut menggambar balok yang bagian bawahnya sudah ditulisi masing-masing simbol dari rumus volume balok.
Pada soal nomor dua yang mengukur kemampuan literasi Matematika level 2 tersebut, siswa disajikan soal yang rutin yang mudah dikenali oleh siswa karena digunakan dalam kehidupan sehhari-hari. Pada soal tersebut, disajikan informasi tunggal berupa panjang, lebar, dan tinggi tempat pensil tersebut. Dimana, siswa diharapkan dapat menentukan volume dari tempat pensil tersebut setelah siswa membaca informasi yang diperoleh dari soal. Adapun jawaban SPR pada soal nomor dua dapat dilihat pada gambar 2 berikut.

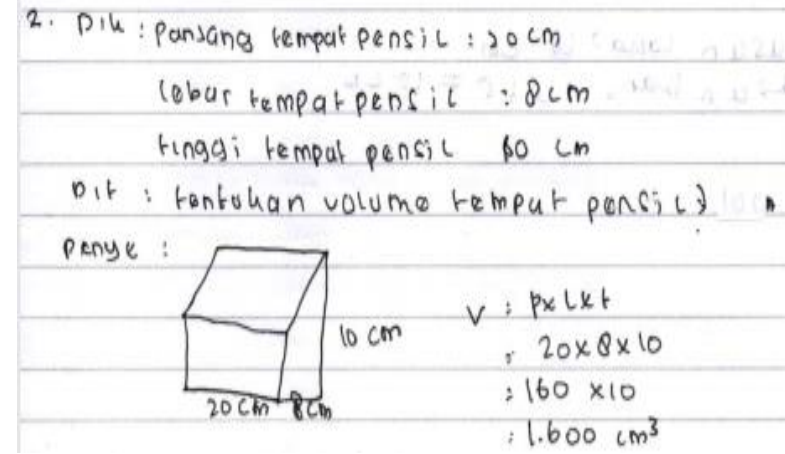

Gambar 2. Jawaban SPR untuk Soal Nomor 2

Untuk soal nomor dua, SPR dapat menjawab dengan benar, siswa tersebut memberikan jawaban yang lengkap mulai dari apa yang diketahui dari soal, apa yang ingin dicari, dan sampai kepada cara penyelesaian dari masalah yang ada pada soal tersebut. Dalam hal ini, SPR dapat menafsirkan dan memilih informasiinformasi penting yang relevan dengan soal. Sehingga, SPR langsung menarik kesimpulan bahwa rumus yang digunakan untuk 
menyelesaikan soal tersebut adalah rumus volume balok yang dituliskan sesuai dengan prosedur atau langkah-langkah pengerjaan yang terstruktur. Selain itu, SPR selalu menyertakan gambar ketika mengerjakan suatu soal. Namun pada soal nomor dua yang dikerjakan tersebut, gambar yang dibuat lebih mengarah pada gambar kubus bukannya balok.
Selanjutnya pada soal yang mengukur kemampuan literasi Matematika level 3, siswa diharapkan dapat menerapkan strategi yang sederhana untuk dapat menentukan lebar kotak makan milik Ayu tersebut dan mengerjakannya dengan prosedur maupun langkah-langkah yang jelas. Adapun jawaban SPR untuk soal nomor tiga dapat dilihat pada gambar 3 berikut.

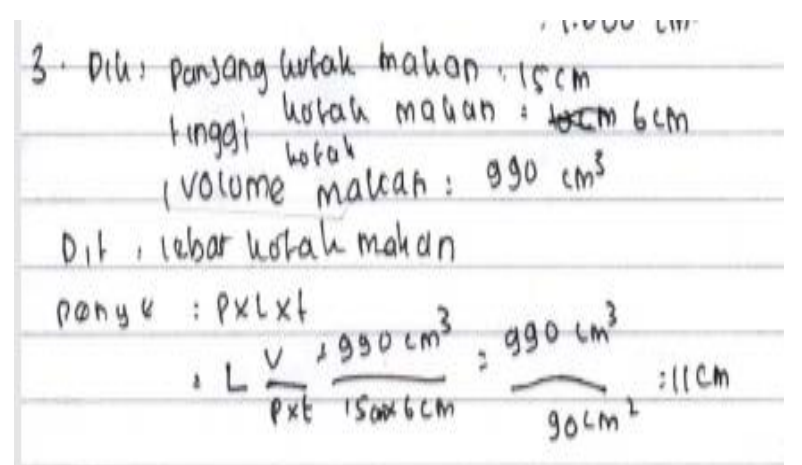

Gambar 3. Jawaban SPR untuk Soal Nomor 3

Untuk soal nomor tiga, SPR dapat menjawabnya dengan benar. Siswa dapat memberikan jawaban yang lengkap, mulai dari menuliskan informasi yang diketahui dari soal, apa masalah dari soal tersebut, dan cara penyelesaian masalah yang ada pada soal tersebut. SPR dapat memecahkan masalah dalam soal tersebut dengan menggunakan strategi rumus yang sederhana yaitu dengan menggunakan rumus volume balok yang dibalik. Selain itu, SPR dapat memberikan jawaban dengan prosedur pengerjaan yang jelas dan dikerjakan secara berurutan. SPR dapat menafsirkan dan menggunakan pandangannya terkait dengan informasi yang diperoleh dari soal untuk menyelesaikan masalah dari soal tersebut.

Di sisi lain, terdapat tiga soal yang belum dapat dikerjakan dengan baik, yaitu soal nomor empat, lima, dan enam yang mengukur kemampuan literasi level 4, 5 dan 6. Untuk lebih jelasnya, berikut adalah jawaban SPR untuk nomor satu, dua, dan tiga

Untuk mendapatkan hasil yang lebih akurat mengenai kemampuan literasi SPR, peneliti melakukan wawancara mendalam terkait hasil tesnya dalam menyelesaikan soal nomor satu, dua, dan tiga yang mengukur kemampuan literasi Matematika level 1, 2, dan 3. Wawancara tersebut dilakukan pada tanggal 10 Maret 2020. Adapun hasil wawancara terkait jawaban SPR (Subjek Penelitian Reflektif) yang dilakukan oleh PSR (Peneliti Subjek Reflektif) pada soal nomor satu sampai tiga adalah sebagai berikut :

\footnotetext{
PSR : bagaimana nak sudah siap ibu wawancarai ?

SPRD : iye sudah bu

PSR : coba kita perhatikan soal dan jawabanta nomor tiga

SPRD : sudah say abaca bu

PSR : apa yang kita pahami dari soal nomor 3 ?

SPRD : Ayu memiliki tempat makan yang berbentuk balok bu
} 


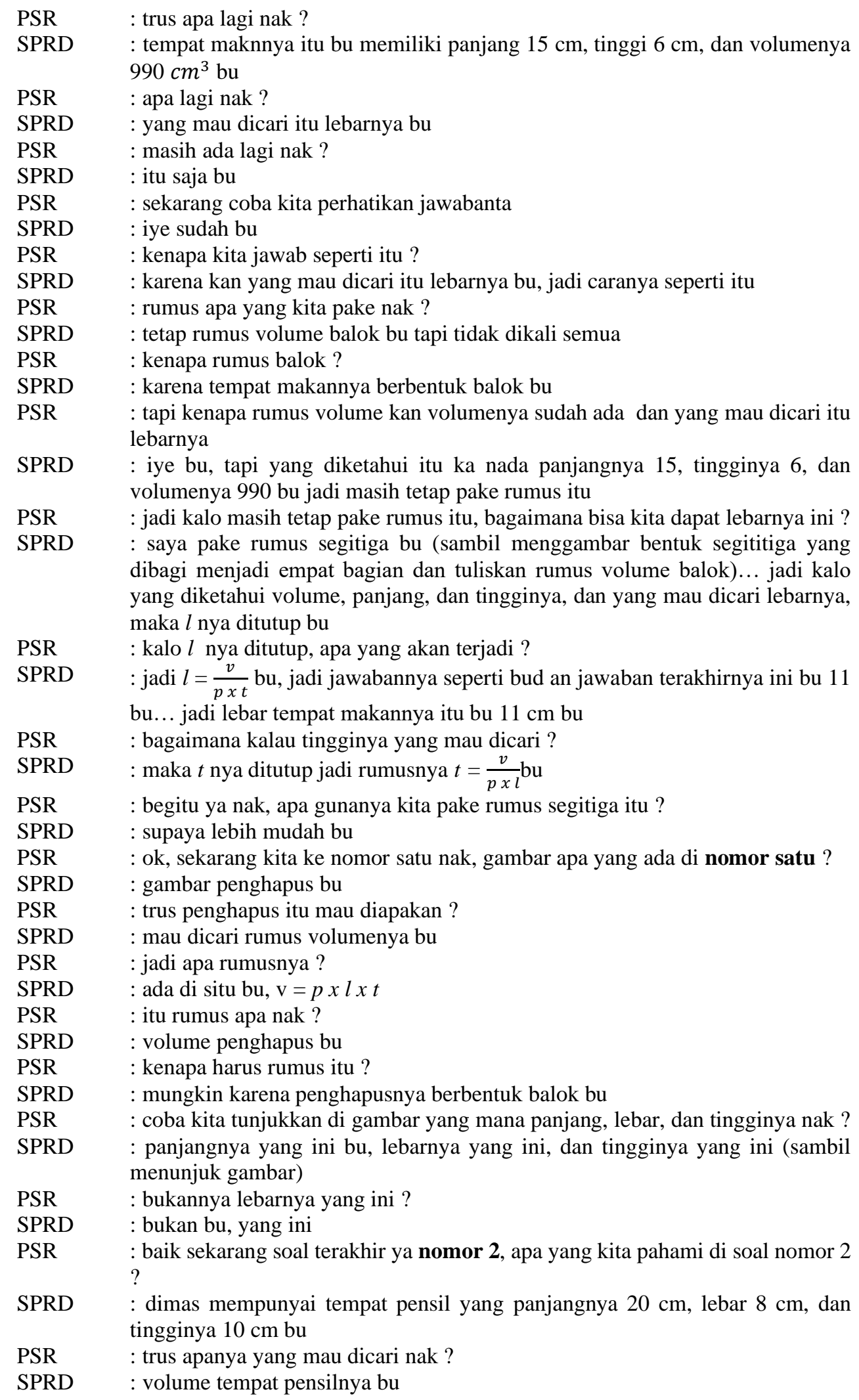




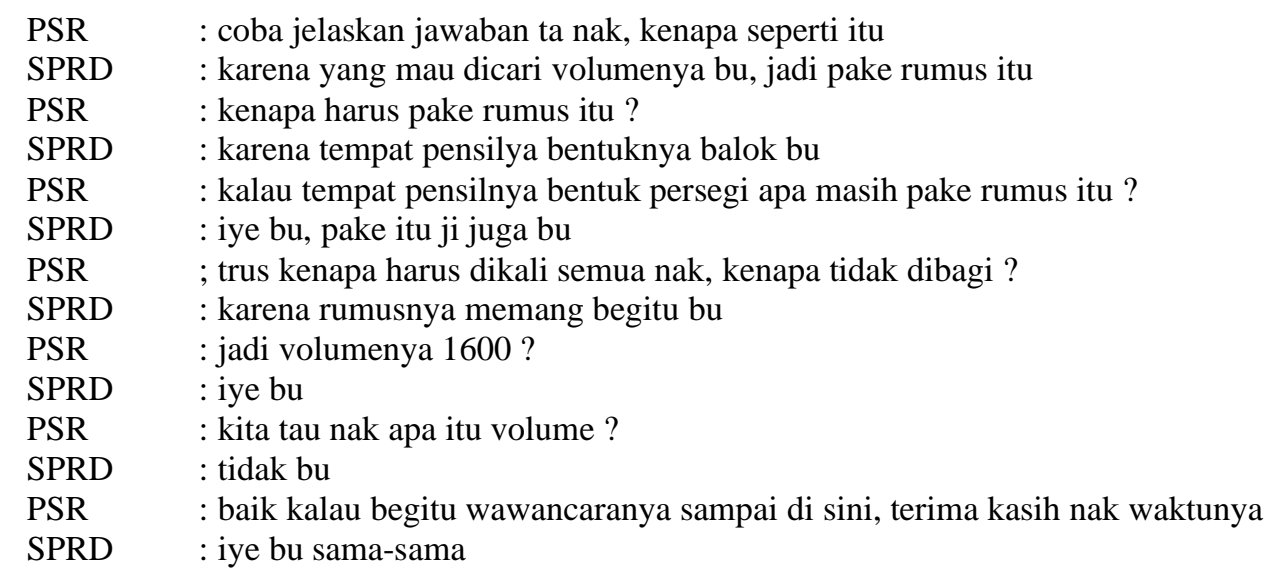

Setelah melakukan wawancara kepada SPR, dari hasil wawancara tersebut dapat dipaparkan bahwa pada soal nomor tiga, siswa tersebut dapat menjelaskan dengan baik informasi yang diperoleh dari soal tersebut, apa masalah dari soal tersebut, dan cara penyelesaian masalahnya. SPR dapat memecahkan masalah dengan menerapkan strategi sederhana, dia dapat menjawabnya dengan trik rumus segitiga untuk mendapatkan rumusnya mencari lebar kotak makan Ayu yang rumus dasarnya menggunakan rumus volume balok. Sehingga SPR dapat menyelesaikannya sesuai dengan prosedur atau langkah demi langkah secara berurutan. Selain itu, siswa tersebut juga dapat menjelaskan dengan baik mengapa dia menggunakan rumus tersebut dan dari mana rumus tersebut diperoleh.

Kemudian untuk soal nomor satu, SPR dapat menjawab pertanyaan dari gambar penghapus tersebut. Namun ketika siswa tersebut diberikan stimulus untuk mengidentifikasi yang mana panjang, lebar, dan tingginya pada gambar penghapus tersebut, SPR tidak dapat menunjukkannya dengan benar, siswa tersebut menunjuk bagian panjang dari penghapus sebagai lebarnya. Ketika ditanya ulang, siswa tersebut tetap menjawab bahwa jawabannya adalah benar.

Selanjutnya untuk soal nomor dua, SPR dapat memberikan jawaban yang benar pada tes tertulis. Tetapi ketika diwawancarai, SPR hanya mampu menjelaskan apa yang diketahui dan apa yang ingin dicari dari soal tersebut, namun tidak mampu memberikan alasan yang baik dari cara penyelesaian yang dikerjakan. Ketika ditanya, "jika tempat pensilnya berbentuk persegi apakah masih menggunakan rumus volume itu atau tidak", siswa tersebut menjawab bahwa "rumus yang digunakan tetap sama". Hal tersebut menunjukkan bahwa siswa tersebut tidak dapat menyajikan jawabannya dengan penyajian tunggal sesuai dengan informasi yang relevan dari soal tersebut.

Dengan demikian, berdasarkan hasil tes literasi Matematika yang diberikan secara tertulis dan hasil wawancara yang dilakukan oleh peneliti kepada SPR, subjek penelitian reflektif (SPR) memenuhi kriteria level literasi Matematika pada level tiga, yaitu : 1) melaksanakan prosedur dengan jelas, termasuk prosedur yang memerlukan keputusan secara berurutan, 2) memecahkan masalah, dan menerapkan strategi yang sederhana, 3) menafsirkan dan menggunakan representasi berdasarkan sumber informasi yang berbeda dan mengemukakan alasannya secara lansung, dan 4) mengkomunikasikan hasil interpretasi dan alasan mereka. Dengan demikian, siswa reflektif tersebut memiliki kemampuan literasi Matematika level tiga. Deskripsi Kemampuan Literasi Matematika Siswa yang Bergaya Kognitif Impulsif

Berdasarkan hasil temuan pada siswa impulsif tersebut, maka siswa impulsif membutuhkan waktu yang singkat dalam mengerjakan soal. Siswa impulsif cenderung cepat dalam memberikan jawaban tanpa mencermati terlebih dahulu soal yang diberikan, sehingga jawaban yang diberikan cenderung salah. Ketika mengerjakan soal tes literasi Matematika, siswa 
impulsif menyelesaikan soal tes lterasi Matematika dalam waktu 32 menit dari batas waktu yang ditentukan yaitu 90 menit.Setelah diberikan soal tes literasi Matematika kepada siswa impulsif ARS , hasil tes menunjukkan bahwa SPI (ARS) hanya mampu mengerjakan satu soal dengan benar, yaitu soal nomor satu yang mengukur kemampuan literasi Matematika level 1.
Pada soal yang mengukur kemampuan literasi Matematika level 1 tersebut, siswa diberikan soal yang konteksnya umum dan dikenali oleh siswa yaitu gambar penghapus yang berbentuk balok. Kemudian siswa setelah melihat gambar penghapus, diharapkan siswa dapat menentukan rumus volume penghapus pada gambar tersebut. Adapun jawaban SPI pada soal nomor satu dapat dilihat pada gambar 4 berikut.

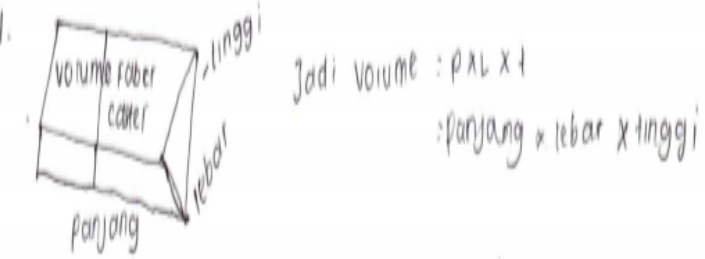

\section{Gambar 4. Jawaban SPI untuk Nomor 1}

Dari hasil pengerjaan SPI tersebut pada soal nomor satu, dapat dilihat bahwa siswa tersebut dapat mengerjakan soal nomor satu dengan benar. Siswa tersebut dapat menuliskan rumus volume penghapus dengan baik yang disertai dengan gambar dan dapat menuliskan arti dari masingmasing simbol tersebut. Hal tersebut menunjukkan bahwa SPI dapat menjawab pertanyaan dengan konteks yang dikenalnya berupa gambar penghapus yang berbentuk balok serta dapat mengidentiffikasi gambar tersebut yang mana bagian panjang, lebar, dan tingginya yang dibuat melalui gambar yang menyerupai penghapus.

Di sisi lain, terdapat satu soal yang belum dapat dikerjakan dengan baik, yaitu soal nomor dua yang mengukur kemampuan literasi level 2. Dimana, SPI salah memasukkan angka untuk lebar tempat pensil Dimas, sehingga hasil akhirnya salah. Sedangkan untuk soal nomor tiga sampai nomor enam yang mengukur kemampuan literasi level 3, 4, 5, dan sampai 6, SPI tidak dapat mengerjakannya dengan benar dan hanya asal menjawab. Untuk lebih jelasnya, berikut adalah jawaban SPI untuk nomor satu.

Untuk mendapatkan hasil yang lebih akurat mengenai kemampuan literasi SPI, peneliti melakukan wawancara terkait hasil tesnya dalam menyelesaikan soal nomor satu yang mengukur kemampuan literasi Matematika level 1. Wawancara tersebut dilakukan pada tanggal 11 Maret 2020. Adapun hasil wawancara terkait jawaban SPI(Subjek Penelitian Impulsif) yang dilakukan oleh PSI (Peneliti Subjek Impulsif) pada soal nomor satu adalah sebagai berikut :

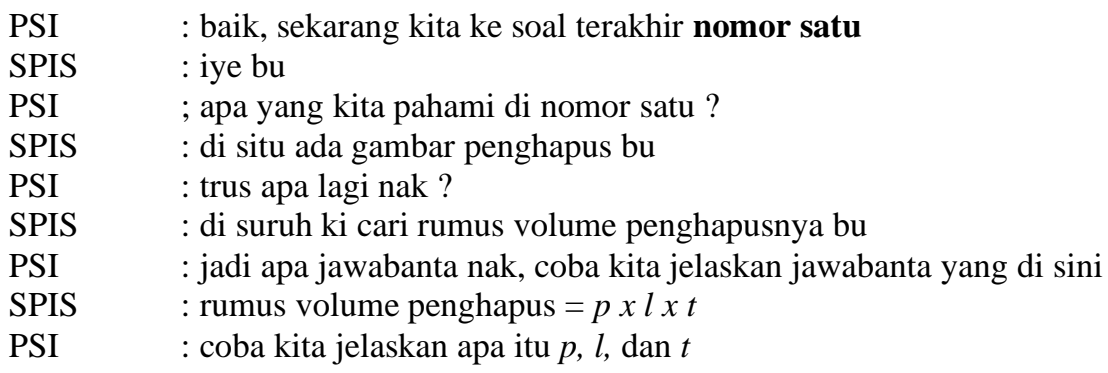




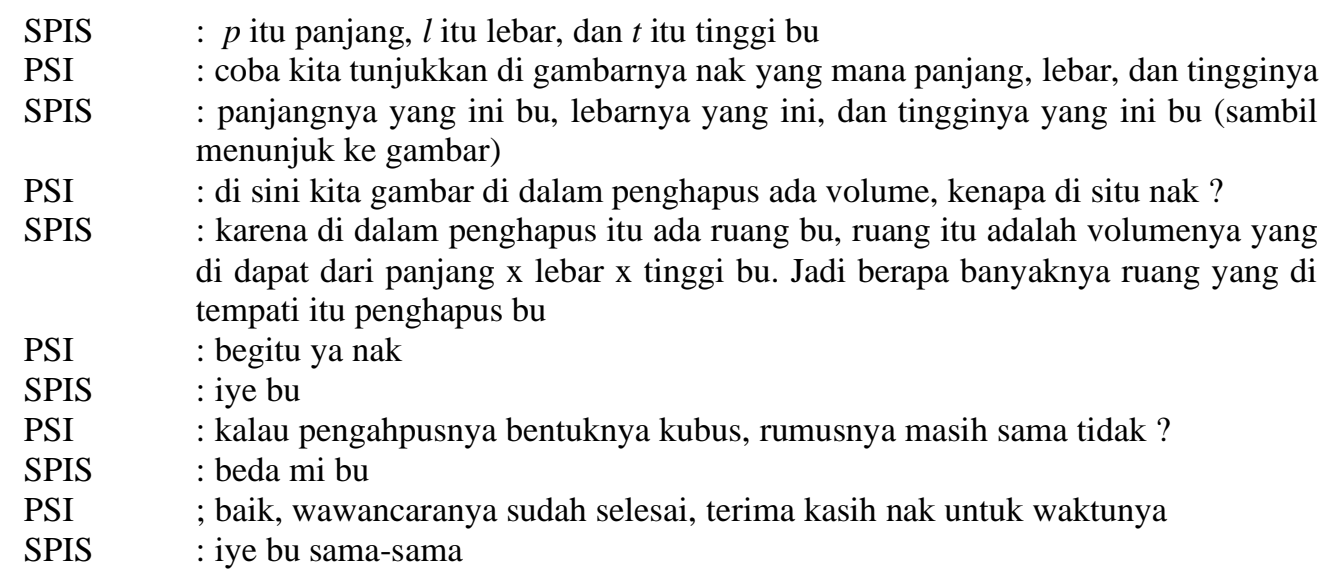

Setelah melakukan wawancara kepada SPI, dari hasil wawancara tersebut dapat dipaparkan bahwa pada soal nomor satu, SPI dapat menjawab pertanyaannya dengan baik dan menjelaskan alasan dari jawabannya dengan jelas. SPI dapat mengidentifikasi gambar penghapus tersebut dengan baik sesuai dengan apa yang dia kenali dari gambar tersebut berdasarkan instruksi yang jelas. Selain itu, dia juga dapat menjelaskan dengan baik kepanjangan dari setiap rumus yang dituliskan dan dapat menunjukkan yang mana panjang, lebar, dan tinggi dari gambar penghapus tersebut sesuai dengan stimulasi yang diberikan serta dapat menjelaskan apa itu volume. SPI juga dapat membedakan rumus yang digunakan ketika gambarnya berbentuk balok dan persegi.

Dengan demikian, berdasarkan hasil tes literasi Matematika yang diberikan secara tertulis dan hasil wawancara yang dilakukan oleh peneliti kepada SPI, subjek penelitian impulsif (SPI) memenuhi kriteria level literasi Matematika pada level satu, dimana siswa tersebut mampu : 1) menjawab pertanyaan dengan konteks yang dikenal serta semua informasi yang relevan tersedia dengan pertanyaan yang jelas, 2) mengidentifikasi informasi, dan melakukan caracara yang umum berdasarkan instruksi yang jelas, serta 3) menunjukkan suatu tindakan sesuai dengan stimulasi yang diberikan. Dengan demikian, siswa impulsif terpilih memiliki kemampuan literasi Matematika level satu

\section{SIMPULAN DAN REKOMENDASI}

Berdasarkan hasil analisis kemampuan literasi Matematika yang ditinjau dari gaya kognitif pada siswa kelas VI SD Inpres Nipa-Nipa yang dilihat dari hasil tes literasi Matematika dan hasil wawancara kepada subjek penelitian, maka dapat ditarik disimpulkan bahwa : 1) Siswa yang memiliki gaya kognitif reflektif cenderung lebih akurat dan selalu berhati-hati dalam mengerjakan soal. Ketika diberikan tes literasi Matematika, siswa tersebut dapat menyelesaikan soal dengan waktu 98 menit dari batas waktu maksimum yaitu 90 menit. Kemudian setelah dilakukan wawancara terkait jawaban siswa reflektif pada tes literasi Matematika, maka diperoleh hasil bahwa siswa reflektif mampu : mengenali soal dengan memberikan kesimpulan langsung, dapat memberikan informasi yang relevan, dapat menggunakan rumus dasar, dan dapat memberikan alasan yang tepat dari jawaban yang diberikan. Dengan demikian, berdasarkan hasil tes literasi Matematika dan hasil wawancara, siswa reflektif tersebut memenuhi kriteria level literasi Matematika pada level tiga sehingga memiliki kemampuan literasi Matematika level tiga.

Selanjutnya 2) Siswa yang bergaya kognitif impulsif kelihatan lebih tergesa-gesa dalam mengerjakan soal dan jawabannya cenderung salah karena sering kali memberikan jawaban yang kurang akurat. Ketika diberikan tes literasi Matematika, siswa tersebut menyelesaikan soal dengan waktu 32 menit dari batas waktu yang ditentukan yaitu 90 menit. Kemudian setelah 
dilakukan wawancara terkait jawaban siswa impulsif pada tes literasi Matematika, maka diperoleh hasil bahwa siswa impulsif tersebut mampu : menjawab pertanyaan dengan konteks yang dikenal, dapat mengidentifikasi bagianbagian dari penghapus, dan mampu menunjukkan tindakan sesuai dengan stimulasi yang diberikan. Dengan demikian, berdasarkan hasil tes literasi Matematika dan hasil wawancara, siswa impulsif memenuhi kriteria level literasi Matematika pada level satu sehingga siswa impulsif tersebut memiliki kemampuan literasi Matematika level satu.

Adapun saran-saran dari peneliti terkait dengan hasil penelitian yang dilakukan adalah sebagai berikut : 1) Disarankan kepada guru, agar membiasakan siswa untuk mengerjakan soal-soal penalaran yang berkaitan dengan kehidupan sehari-hari khususnya untuk siswa kelas VI agar siswa tersebut terbiasa menghadapi soal-soal yang menuntut strategi penyelesaian masalah. Selain itu, diharapkan guru mampu mengembangkan pembelajaran dengan menggunakan pendekatan pembelajaran yang dapat menumbuhkan kemampuan literasi Matematika siswa, salah satunya dengan pendekatan realistik matematik. 2) Bagi peneliti yang berminat mengembangkan lebih lanjut penelitian ini, diharapkan mencermati keterbatasan penelitian ini, sehingga penelitian selanjutnya dapat menyempurnakan penelitian ini.

\section{DAFTAR PUSTAKA}

Abidin, Y., Mulyati, T., dan Yunansah, H. (2017). Pembelajaran Literasi :Strategi Meningkatkan Kemampuan Literasi Matematika, Sains, Membaca, dan Membaca. Jakarta: Bumi Aksara.

Aprilia, N.C., Sunardi, dan Trapsilasiwi, D. (2015). "Proses Berpikir Siswa Gaya Kognitif Reflektif dan Impulsif dalam Memecahkan Masalah Matematika di Kelas VII SMPN 11 Jember". Jurnal Edukasi. Vol. 2, No. 3, Hal 31-37.

Ayuningtyas, N. (2017). "Profil Literasi Matematis Konten Change and Relationship Siswa Kelas X Ditinjau dari Gaya Kognitif Visualizer dan Verbalizer". Jurnal Edukasi. Vol. 3, No. 1, Hal 99-109.
BSNP. (2006). Standar Isi untuk Satuan Pendidikan Dasar dan Menengah. Jakarta: BSNP.

Desmita. (2009). Psikologi Perkembangan Peserta Didik. Bandung: PT Remaja Rosdakarya Offset.

Fadiana, M. (2016). “ Perbedaan Kemampuan Menyelesaikan Soal Cerita antara Siswa Bergaya Kognitif Reflektif dan Impulsif". Journal of Research and AdVances in Mathematics Education. Vol. 1, No. 1, Hal 79-89.

Fathani, A.H. (2016). "Pengembangan Literasi Matematika Sekolah dalam Perspektif Multiple Intelligences". Edusains. Vol. 4, No. 2, Hal 136-150.

Ghony, M.D., dan Almanshur, F. (2017). Metodologi Penelitian Kualitatif. Jogjakarta : Ar-Ruzz Media.

Ghufron, N., dan Risnawita, R. (2014). Gaya Belajar : Kajian Teoritik. Yogyakarta: Pustaka Belajar.

Hasanah, U., Wardono, W., dan Kartono, K. (2016). Keefektifan Pembelajaran MURDER Berpendekatan PMRI dengan Asesmen Kinerja Pada Pencapaian Kemampuan Literasi Matematika Siswa SMP Serupa PISA. Unnes Journal of Mathematics Education (Vol. 5 No. 2)

Isrok'atun, dan Rosmala, A. (2018). MoodelModel Pembelajaran Matematika. Jakarta: Bumi Aksara.

Kagan, J. (1965). ImpulsiVe and ReflectiVeChildren: Significance of Conceptual Tempo.Dalam Krumboltz, J.D (Eds.) Learning and theEducational Process. Chicogo.Rand Mc Nally \& Company.

Kemendikbud. (2016). "Peringkat dan Capaian PISA" dalam https://www.kemdikbud.go.id. Diakses Minggu, 13 Januari 2018.

Kenny, Robert F. (2007). Digital NarratiVe as a ChangeAgent to Teach Reading to MediaCentric Students.International Jurnal of Social Sciences. Vol. 2,No. 3. 
Moleong, L. J. (2018). Metodologi Penelitian Kualitatif. Bandung : PT. Remaja Rosdakarya.

Mulidi, A. (2016). "Pengertian Literasi dan Perkembangannya" dalam http://www.kanalinfo.web.id. Diakses Minggu,12 Mei 2019.

Mulyati, T. (2017). "Kemampuan Pemahaman Membaca, Berpikir Kritis dan Berpikir Kreatif Matematis Siswa Melalui Pembelajaran Pemecahan Masalah SQ RQ CQ Model Integratif dengan Literatur Anak". Disertasi Bandung: UPI. (tidak diterbitkan).

Mulyono, A. (2012). Anak Berkesulitan Belajar: Teori, Diagnosis, dan Remediasinya. Jakarta: PT Rineka Cipta.

Nasution, S. (2010). Berbagai Pendekatan dalam Proses Belajar dan Mengajar. Jakarta: PT. Bumi Aksara.

Nisa, R. (2016). "Profil Berpikir Kritis Siswa SMP dalam Menyelesaikan Soal Cerita Ditinjau dari Gaya Kognitif dan Kemampuan Matematika". Jurnal Apotema. Vol. 2, No. 1, Hal 66-76.

Nurdianasari, H. (2015). "Analisis Kemampuan Literasi Matematika Siswa Kelas VIII Berdasarkan Gaya Kognitif dalam Pembelajaran PMRI". Semarang: UNNES. (Tesis tidak diterbitkan).

OECD. (2013). PISA 2012 Assesment and Analytical Framework. Kanada: OECD.

Ojose, B. (2011). "Mathematics Literacy :Are We Able tp Put the Mathematics We Learn into EVeryday Use? Journal of Mathematics Education (Vol. 4 No. 1).

OVan, Waluya S.B., dan Nugroho S.E. (2018). "Analysis Mathematical Literacy Skills in Terms of the Students' Metacognition on PISA-CPAS Model". Journal International Conference on Mathematics, Sciensce and Education.

Priyatni, E.T., Hamidah, S.C., dan Adi, P. (2017). Pembelajaran Reflektif : Model Pembelajaran Reflektif yang Responsif Teknologi. Tangerang: Tira Smart.
Putra, N. (2013). Metode Penelitian Kualitatif Pendidikan. Jakarta: PT Raja Grafindo Persada.

Rahman, A. (2000). Al-Qur'an Sumber Ilmu Pengetahuan, Jakarta: Rineka Cipta.

Rozencwajg, P., \& Corroyer, D. (2005). CognitiVeProcesses in the Refl ectiVeImpulsiVe CognitiVeStyle. The Journal of Genetic Psychology. Vol. 166, No. 4, Hal. $451-463$.

Setiawan, H., Dafik, dan Diah, N. 2014. "Soal Matematika dalam PISA Kaitannya dengan Literasi Matematika dan Keterampilan Berpikir Tingkat Tinggi”. Jurnal Prosiding Seminar Nasional Matematika : UniVersitas Jember.

Slameto. (2010). Belajar dan Faktor-faktor yang Mempengaruhinya. Jakarta: Rineka Cipta.

Sugiyono. (2015). Metode Penelitian Pendidikan : Pendekatan Kuantitatif, Kualitatif, dan $R$ \& D. Bandung: Alfabeta.

Syawahid, M., dan Putrawangsa, S. (2017). "Kemampuan Literasi Matematika Siswa SMP Ditinjau dari Gaya Belajar". Jurnal Tadris Matematika. Vol. 10, No. 2, Hal 222-240.

Ulya, H. (2015). "Hubungan Gaya Kognitif dengan Kemampuan Pemecahan Masalah Matematika Siswa". Vol. 1, No. 2.

Warli. (2010). "Kreativtas Pemecahan Masalah Siswa SMP. Jember. Kadikma. Jurnal Matematika dan Pendidikan Matematika. Vol. 2, No. 1, Hal 110

Warli. (2013). "Kreativitas SMP yang bergaya Kognitif Reflektif atau Impulsif dalam Memecahkan Masalah Geometri. Jurnal Pendidikan dan Pembelajaran.Vol. 20, No. 2, Hal 190 - 201.

Zairozie, A.Z. (2016). "Fungsi Kognitif Siswa Smp Dalam Menyelesaikan Soal Geometri Ditinjau Dari Gender". Prosiding Seminar Nasional Pendidikan Matematika. Madura: Universitas Madura. 